\title{
Assessment of the Operation of the 24-hour Convenience Stores in Tagbilaran City, Bohol, Philippines
}

\author{
ADRIANNA KYLA M. SEVILLA \\ http://orcid.org/0000-0002-9683-2965 \\ kylasevilla@ymail.com \\ ISABEL IRIS T. GARSUTA \\ http://orcid.org/0000-0002-5392-3947 \\ rainbelle99@gmail.com \\ VANESSA P. ACHACOSO \\ http://orcid.org/0000-0002-9776-7990 \\ vanessachacoso2018@gmail.com \\ MARIANNE DAPHNY R. TARE \\ http://orcid.org/0000-0003-0966-5909 \\ mariannetare@gmail.com \\ ALEXIS JOHN P. ANINO \\ http://orcid.org/0000-0002-9924-6830 \\ alexisanino@gmail.com
}

\begin{abstract}
Round-the-clock establishments are no longer just for manufacturing but also for raising productivity and lowering costs in a wide-range of industries. This study looked into the nature and operation of 24-hour convenience stores in Tagbilaran City, Bohol, with the objective to provide proper guidance and adequate information for entrepreneurs who are planning to increase and expand 24-hour convenience stores within the city. The re-
\end{abstract}


searchers utilized the quantitative method with purposive sampling design with managers or proprietors and the convenient sampling design with 48 customers of such stores. Data were treated using percentages, weighted mean, t-test, and chi-square. Results showed that store owners made maximum use of time, equipment, and people; designed solutions for costly problems of morale, health, safety, care for employees through benefits; and the disadvantages and advantages of running 24-hour convenience stores. The findings suggest that though the customers' convenience of not being rushed due to fear of closing hours, the need for the huge investment coupled with the challenge of getting employees willing to work on midnight shifts made these convenience stores challenging businesses to start up. The study found that contrary to general belief; these stores do not guarantee any economic stability during a national economic crisis. Such stores also do not help last-minute customers, given limited commodities.

Keywords: Business research, feasibility study, convenience store, quantitative method, t-test, chi-square, Tagbilaran City, Bohol, Philippines, Asia

\section{INTRODUCTION}

Convenience stores are defined as most often franchised markets that are open for many hours in a day. In a year, there are 8,760 hours for convenience stores to operate. There are establishments and businesses that use all those hours as effectively as they could. These 24-hour convenience stores are no longer just for manufacturing; they also ventured for raising productivity, and for lowering costs in a wide-range of industries (Coleman, 1995).

Looking at the global context, specifically in Southeast Asia, these stores that are open $24 / 7$ are hardly being reconsidered. In Japan, the moves to limit 24-hour convenience stores are due to environmental and lifestyle concerns. Hiroshi Ando, a Japanese official, explicitly stated that these stores eat up too much electricity. Also, because of the cultural difference around the globe, Japanese citizens live a morning-set lifestyle, wherein they do everything in the morning and rest at night, which means they do not have the reasons and potential to go to a 24-hour convenience store (Fukada, 2008). These types of establishments are globally ubiquitous. Among 90 percent of the shops listed in the American National Association of Stores 
(ANAS) are open for 24 hours, 7 days a week. It is because of the accessibility of these stores that owners said they get a cross-section of customers that made them push through with the stores.

In the local context, Tagbilaran City which is the capital of Bohol is the main center for commerce, trade, and industry, health, entertainment, and education. There are 15 communities comprising Tagbilaran, with a population of 105,051 in the census for the year 2015, and an annual growth rate of $1.57 \%$. Forty-four percent of the city's population resides in the four urban districts where trade and commerce are also concentrated (Philippine Statistics Authority, 2016). There are more than 25 convenience stores in the city. About ten branches are from the same corporation, which leads us to think that expansion of these stores in this city is very beneficial both to the customers and managers.

Although the city is not foreign to the establishment of 24-hour convenience stores, the rate of these stores' growth in population is still not at its peak. These stores do not grow parallel to the needs of the Tagbilaranons even at midnight until dawn. Since Tagbilaran, a booming city is still busy even at night and at dawn, people are always on the lookout for 24-hour convenience stores that could cater to their needs when the malls and the convenience stores operating during normal hours are closed. Only a few businessmen were able to acquire the means and requirements for a convenience store to operate for 24 hours.

The benefits of this study address the concern mentioned above. The researchers looked deep into the nature and operation of 24-hour convenience stores here in Tagbilaran through the perspectives of their owners, CEOs, or managers. The researchers identified how the mentioned examples made maximum use of time, equipment, and people; designed solutions for costly problems of morale, health, safety, care for employees through benefits; and the disadvantages and advantages of running stores round-the-clock to provide proper guidance and adequate information for businessmen who are planning to increase and expand the number of 24hour convenience stores in Tagbilaran City to meet the needs of Tagbilaranons.

The Theory of Constraints where Eliyahu M. Goldratt was the proponent (Goldratt, 1990) backed the theoretical underpinning of the study. A kind of methodology that captured the essential limiting factor (i.e., constraint) that stands in the way of achieving a goal and then systematically improving that constraint until it is no longer the limiting factor. The Theory of Consumer 
Behavior by Alfred Marshall states that our analysis of demand permits us to determine the underlying factors affecting the level of consumer demand of a given commodity. An increase in the price of a commodity, we expect consumers to react by decreasing the quantity they want to buy.

Furthermore, the Law of Demand is a microeconomic law by Alfred Marshall that states, all other factors being held equal, as the price of a good or service increases, consumer demand for the good or service will decrease, and vice versa. From a service perspective, it is possible to identify two critical dimensions of service performance: performance relative to operational elements and performance relative to relational elements (Stank, Goldsby \& Vickery (1999). The operational elements consist of activities performed by service providers that contribute to productivity, efficienc , and consistent quality. An operation of a business is one of the main factors of customer loyalty and satisfaction. It refers to the overall business performance of a certain establishment with regards to its classification. Convenience stores must operate as to the convenience of the customers, from parking lots, employment, commodities, to prices, and security. Operations performance factors for manufacturing firms are well established in the operations literature, which identifies cost, flexibilit , quality, dependability, and accuracy as critical manufacturing competitive priorities (Morash, Dröge \& Vickery, 1997; Slack, Lewis \& Bates, 2004).

As to Cost Performance, Cost is an absolute term and measures the amount of resources used to produce the product. Slack and Lewis (2002) stress that all producers, even those whose primary source of competitiveness is different from product selling prices, will be interested in keeping their costs low. As an addition to overall profits translates from every peso removed from the operation's overall cost. Hence, as Slack and Lewis (2002) suggested, this concept concluded that the essential factor is the cost performance of various operational performance dimensions (Slack and Lewis, 2002). Although in most cases, such is ranked least significant in empirical studies (e.g., Boyer and Lewis, 2002).

As to Flexibility Performance, a property that distinguishes flexibility from other dimensions of operational performance is that it is a measure of potential rather than actual performance. Also, the level of flexibility is not directly evaluated by the customer; it is more of an operational means to provide possibilities for more customized products and product deliveries (Slack, 1983). Flexibility can thus be referred to as an enabler, enabling the manufacturing system to offer shorter delivery lead times, more exten- 
sive product range, among others. The externally visible properties of a highly flexible manufacturing system include an extensive product range, significant opportunities for product customization and highly flexible delivery times (Slack, 1983).

Regarding Quality Performance, quality is a multifaceted term. According to Garvin (1987) quality can be viewed from up to eight different perspectives: performance, features, reliability, conformance, durability, serviceability, aesthetics, and perceived quality. Within manufacturing operations, the conformance dimension is most influential since it refers to the process' ability to produce products to their predefined specification reliably and consistently (Slack and Lewis, 2002). High levels of conformance quality must be attained before trying to improve any other of the performance dimensions (Ferdows and De Meyer, 1990). Customer satisfaction is often regarded as the prime measure of external quality performance (e.g., Anderson and Sullivan, 1993). Operational performance affects customer loyalty, which affects demand, which then affects the ability of expansion.

Regarding the Development of Convenience Stores, the operation of convenience stores (CVS) is facing a crossover revolution by providing multiple services, including daily fresh foods, and groceries. It means the convenience stores may provide greater access to foods and beverages than supermarkets or small grocery stores and thus, influence food choice and consumption. During these years, intensifying competition in the retail industry has been getting more and more centralized and diversified. As a fast-developing retail sector, convenience stores have taken much more burden than they used to, the most important one being how to maintain the attraction to customers for a convenience store. Today's convenience store retailing environment is hypercompetitive. Sustainable advantage gives way quickly as competitors scurry to copy innovations in operations and supply-chain management, implement similar technology, and mimic the store merchandising.

In the convenience store industry, location is one of the most significant issues to settle with to create easy and doable access to the products. Rainisto (2003) mentioned that location or place is one of the most critical factors in retailing success and the key to its ability to attract customers. Also, the right location or place can diminish the cost of transportation and time and raise goods delivery system smoothly. These can affect consumer satisfac-tion. Convenience stores are placed in accessible locations. The location should be close to where they live, where they work, or on their normal route to and from or work. Also, location to be convenient, must have 
easy access and egress, and convenient parking spaces for customers who only want to shop in the store and to get in and out quickly. The right location provides both convenience and value.

A study by Chen and Quester (2006) developed a model of customer store loyalty for retail service based on a value-based market orientation practice, staff performance and customer satisfaction. Researchers consid-ered coming up with measurements by considering both the perspectives of both the firms and consumers. An approach of dyadic data collection was used upon which the model was then tested empirically in a retail setting in Taiwan, For each service provider from a random sample of hairdressing sa-lons in Taiwan included in the survey, a matched set of customers provided information concerning their expectation and evaluation of service. Study outcomes yielded the effect of the value perceived by customers about the practice of market orientation and so with its impact on the retention of customers. The model emphasized the importance that marketing practitioners should manage customer satisfaction. Also, the need to highlight the value perceptions and implementation of market orientation as those are directly related to customer store loyalty.

By applying Kano model, the study attempts to investigate the categorization of home delivery quality elements derived from service convenience model and their impact on customer satisfaction. The researchers made a thorough literature review on framework and hypotheses. The application of Kano model to classify the home delivery service elements into five quality attributes and gender is included to understand the difference of customer perception on the obtained quality elements. Statistical analyses of the collected questionnaires were computed based on the effective responses regarding the home delivery service. The results confirmed that customers' perception of home delivery service elements is classified into mustbe onedimensional attributes by Kano model while contributing to the creation of attractive elements that significantly affect customer satisfaction and possesses enormous potential to further differentiate competitors. Customer satisfaction is positively correlated with different types of service convenience. The results also suggest that customers of different genders have significantly different views to quality elements of home delivery service.

In the study of McDonnell, Beatson \& Huang (2001), they attempted to empirically examine some important elements (e.g., relationship quality, 
loyalty, and cooperation) that might promote a successful long-term franchising relationship between franchisers and franchisees of convenience stores in Taiwan. A total of 500 surveys were mailed to a random sample of convenience stores' franchisees among the four main franchisers in Taiwan. This research first used correlation analysis to explore the associations between the constructs and then used a regression analysis to further explore pat-terns of associations. The results showed that relationship quality is positively correlated with the cooperation between franchisers and franchisees, as well as with franchisee loyalty. Additionally, the cooperative behavior between franchisees and franchisers is significantly correlated with franchisees' loyalty. The data were only collected through the said convenience stores franchises systems.

To develop a more inclusive and global perspective, further replications of this study are necessary to examine the stability of our results in other contexts. It has highlighted that small business owners operating in a franchise system should pay attention to the importance of relationship quality, loyalty, and cooperation in stabilizing franchising relationships and enhancing competitive advantage. The majority of studies on franchising relationships have almost been exclusively conducted in a Western context. To date, there have been little to no studies that explore the interaction be-tween relationship quality, loyalty, and cooperation in a franchising relation-ship in an Eastern context.

This study sought to assess the operation of 24-hour convenience stores in Tagbilaran City with the end view of proposed recommendations for future expansions. The study was conducted at five different 24/7 convenience stores in Tagbilaran City.

To maintain the efficiency and feasibility of this study, the researchers limited the study to stores open 24 hours, 7 days a week, and located in Tagbilaran City only. The researchers also limited the type of respondents for feasibility and accuracy. For the entire questionnaires, only proprietors or managers of the said stores answered the questionnaires given, for they are the only ones who could give out the information asked in the questionnaires, specifically the capital, sales, and profit of the business. Customers, however, were also given only Part III of the questionnaires to rate the advantages and disadvantages of having a 24-hour convenience store. 


\section{METHODOLOGY}

To attain the main objectives of this study, the researchers utilized the purposive sampling design to the managers or proprietors and the convenience sampling design to 48 customers of five 24-hour convenience stores in Tagbilaran City with the use of questionnaires as survey methods.

The researcher used a self-constructed questionnaire. These questions were based on the studies of Bedell-Pearce (2013) and Gaille (2015). It underwent the process of validity and reliability check. All reproduced copies of the questionnaire were given to the corresponding respondents. The questionnaire of this study consisted of three parts:

Part I of the questionnaire was on the profile of the subjects in the context of age, sex, and educational qualification. Part II dealt with the status of the subject's business in the context of nature, amount of invested capital, security measures, types of goods sold, employee privileges and sales or profit. Part III of the questionnaire was a Likert Scale Form as to the advantages and disadvantages of running a 24-hour convenience store.

Likert Scale:

1-1.74 = Disagree

1.75-2.49 = Slightly Agree

2.50-3.24 = Moderately Agree

3.25-4 = Strongly Agree

As the norm of the University of Bohol, the proposal underwent an Ethics review to ensure the "do-no-harm" is observed in the entire conduct of the study. The informed consent was secured after the researchers explained the intentions of the study. To assure the confidentiality of the data, the researchers anonymized the captured data by attributing codes instead of names. Lastly, they obtained the signatures of the respondents when they were asked if they were willing to undertake the study.

After collecting the answered tools, the data were gathered and treated using percentages, weighted mean, t-test, and chi-square.

\section{Profile of Respondents}

The profile of the respondents revealed that four out of five respondents $(80 \%)$ that represent the managers of the five 24-hour convenience stores were 20-30 years of age, and only one is between 31 - 
40 years old. Three (60\%) of the respondents were females, and two $(40 \%)$ were males. Among the five respondents, two (40\%) were college graduates, and two (40\%) reached college level. Only one $(20 \%)$ among them was a high school graduate.

\section{RESULTS AND DISCUSSION}

Table 1a reflects the profile of business establishments that include the nature, capital invested, and security measures of the business.

Table 1a. Profile of business establishments

\begin{tabular}{|l|l|l|l|}
\hline Items & Frequency & Percentage & Rank \\
\hline Nature of Business & & & \\
Single Proprietorship & 4 & $80 \%$ & 1 \\
Partnership & 1 & $20 \%$ & 2 \\
\hline Amount of Invested Capital & & & \\
Below P250,000 & 1 & $20 \%$ & 2.5 \\
P250,001- P500,000 & 1 & $20 \%$ & 2.5 \\
P500,001-P1,000,000 & 2 & $40 \%$ & 1 \\
P1,000,001-P2,000,000 & 1 & $20 \%$ & 2.5 \\
\hline 24-Hour Security Plan: & & & \\
With & 4 & $80 \%$ & 1 \\
Without & 1 & $20 \%$ & 2 \\
Security Measures & 2 & $40 \%$ & 2.5 \\
Surveillance Cameras & 2 & $40 \%$ & 2.5 \\
Keys, Padlocks, and Chains to the door & 1 & $20 \%$ & 1 \\
Authentication Devices & & & \\
\hline
\end{tabular}

Nature of the Business. Four (80\%) of the respondents of the 24hour convenience stores were running single proprietorships and one (20\%) was running a partnership.

Amount of Invested Capital. Among the five respondents, two $(40 \%)$ started their businesses with a capital ranging from P500,001$\mathrm{P} 1,000,000$, one $(20 \%)$ started with a capital below P250,000, one $(20 \%)$ started with a capital between P250,001-P500,000, and one (20\%) started with a capital between P1,000,001-P2,000,000.

Security Measures. Of the five respondents, four (80\%) of the businesses had a 24-hour security plan. Only one (20\%) business did not have one.

It was also shown that two of the businesses (40\%) had surveillance cameras, two $(40 \%)$ had keys, padlocks, and chains to the doors, one 
business (20\%) only had the keys to the doors, and one business $(20 \%)$ had authentication devices for authorized personnel. It was also presented that all respondents (100\%) hired 0-2 security guards.

Table 1b. Profile of business establishments (commodities sold, employee wage and employees benefits)

\begin{tabular}{|l|l|l|l|}
\hline Commodities Sold & & & \\
Beverages & 5 & $100 \%$ & 1.5 \\
Canned/ Jarred Goods & 5 & $100 \%$ & 1.5 \\
Dairy & 5 & $100 \%$ & 1.5 \\
Meat & 5 & $100 \%$ & 10 \\
Cleaners & 5 & $100 \%$ & 1.5 \\
Paper Goods & 5 & $100 \%$ & 1.5 \\
Bread/Bakery & 3 & $60 \%$ & 1.5 \\
Dry/Baking Goods & 5 & $100 \%$ & 2 \\
Frozen Foods & 5 & $100 \%$ & 1 \\
Personal Care & 5 & $100 \%$ & 1.5 \\
\hline Employee Wage Per Day & & & \\
P200-400 & 5 & $100 \%$ & 1 \\
\hline Employee Benefit & & & \\
Bonuses & 5 & $100 \%$ & 1.5 \\
PhilHealth Benefit & 5 & $100 \%$ & 1.5 \\
SSS Benefit & 5 & $100 \%$ & 1.5 \\
Union Benefit & 5 & $100 \%$ & 1.5 \\
Night-differential pay & 3 & $60 \%$ & 6 \\
PAG-IBIG Benefi & 1 & $100 \%$ & 1.5 \\
\hline
\end{tabular}

Table 1b depicts the commodities sold, employees' privileges and benefits. As seen in the table, all of the commodities sold were beverages, canned goods, dairy products, cleaners, paper goods, bakery, dry baking goods, frozen food and personal care. Only three businesses $(60 \%)$ sold meat, and no business sold produce.

As to the wage per day, all five respondents (100\%) gave wages that ranged P200-P400 per day. It was also shown that all five respondents $(100 \%)$ provided employee bonuses, PhilHealth, Social Security System, and Union Security benefits. Only three businesses $(60 \%)$ afforded night-differential pay, and only one business $(20 \%)$ provided PAG-IBIG benefits to their employees.

Table 2 illustrates the perceptions of the managers on the advantages of having a 24-hour convenience store. 
Table 2. Advantages of having a 24-hour convenience store (as perceived by the managers)

$\mathrm{N}=5$

\begin{tabular}{|l|l|l|l|l|l|l|l|}
\hline Advantages & SA & MA & SLA & D & WM & DV & Rank \\
\hline $\begin{array}{l}\text { Customers' needs/wants can be } \\
\text { bought anytime. }\end{array}$ & 3 & 2 & 0 & 0 & 3.60 & SA & 3.5 \\
\hline $\begin{array}{l}\text { You do not have to spend much on } \\
\text { marketing because you have a natu- } \\
\text { ral location-based customer segment. }\end{array}$ & 3 & 1 & 1 & 0 & 3.40 & SA & 5 \\
\hline $\begin{array}{l}\text { You have the opportunity to set your } \\
\text { own prices. }\end{array}$ & 4 & 1 & 0 & 0 & 3.80 & SA & 2 \\
\hline $\begin{array}{l}\text { You have a certain level of economic } \\
\text { stability, even when there are down- } \\
\text { turns in the local or national economy. }\end{array}$ & 0 & 4 & 1 & 0 & 2.80 & MA & 7 \\
\hline $\begin{array}{l}\text { The stores will offer more employ- } \\
\text { ment/job opportunities. }\end{array}$ & 0 & 2 & 3 & 0 & 2.40 & SLA & 8 \\
\hline It is relatively easy to get started. & 1 & 3 & 0 & 1 & 2.20 & SLA & 9 \\
\hline $\begin{array}{l}\text { Customers have enough time to buy } \\
\text { commodities without being rushed } \\
\text { because of closing time. }\end{array}$ & 5 & 0 & 0 & 0 & 4.00 & SA & 1 \\
\hline $\begin{array}{l}\text { Employees would earn higher sala- } \\
\text { ries for working for longer hours in } \\
\text { the day. }\end{array}$ & 2 & 1 & 2 & 0 & 3.00 & MA & 5.5 \\
\hline $\begin{array}{l}\text { The stores are helpful for those who } \\
\text { need or want something last minute. }\end{array}$ & 3 & 2 & 0 & 0 & 3.60 & SA & 3.5 \\
\hline It is not hard to find customers & 1 & 3 & 1 & 0 & 3.00 & MA & 5.5 \\
\hline
\end{tabular}

The sixth item listed, which stated, Customers have enough time to buy commodities without being rushed, obtained a mean of 4.00 and a descriptive value of Strongly Agree and was ranked highest. Next in rank as perceived by the managers was item number three, You have the opportunity to set your own prices. It had a weighted mean of 3.80. The third spot with the same weighted mean of 3.60 are items one and eight. Item number 1 stated that Customers' needs or wants can be bought anytime, while item number 8 stated that The stores are helpful for those who need or want something last minute.

Table 3 presents the perspective of the customers as to the advantages of having a 24-hour convenience store. 
Table 3. Advantages of having a 24-hour convenience store (as perceived by the customers)

\begin{tabular}{|l|l|l|l|l|l|l|l|}
\hline Advantage & SA & MA & SLA & D & WM & DV & Rank \\
\hline $\begin{array}{l}\text { 1. Customers' needs/wants can be bought } \\
\text { anytime. }\end{array}$ & 27 & 20 & 1 & 0 & 3.54 & SA & 3 \\
\hline $\begin{array}{l}\text { 2. You don't have to spend much on } \\
\text { marketing because you have a natural } \\
\text { location-based customer segment. }\end{array}$ & 18 & 25 & 5 & 0 & 3.27 & SA & 7 \\
\hline $\begin{array}{l}\text { 3. You have the opportunity to set your own } \\
\text { prices. }\end{array}$ & 29 & 14 & 5 & 0 & 3.5 & SA & 4 \\
\hline $\begin{array}{l}\text { 4. You have a certain level of economic } \\
\text { stability, even when there are downturns in } \\
\text { the local or national economy. }\end{array}$ & 18 & 23 & 7 & 0 & 3.23 & MA & 9.5 \\
\hline $\begin{array}{l}\text { 5. The stores will offer more employment/ } \\
\text { job opportunities. }\end{array}$ & 30 & 17 & 1 & 0 & 3.60 & SA & 2 \\
\hline 6. It is relatively easy to get started. & 18 & 24 & 6 & 0 & 3.25 & SA & 8 \\
\hline $\begin{array}{l}\text { 7. Customers have enough time to buy } \\
\text { commodities without being rushed because } \\
\text { of closing time. }\end{array}$ & 31 & 16 & 1 & 0 & 3.63 & SA & 1 \\
\hline $\begin{array}{l}\text { 8. Employees would earn higher salaries for } \\
\text { working for longer hours in the day. }\end{array}$ & 20 & 25 & 3 & 0 & 3.35 & SA & 5.5 \\
\hline $\begin{array}{l}\text { 9. The stores are helpful for those who need } \\
\text { or want something last minute. }\end{array}$ & 23 & 13 & 12 & 0 & 3.23 & MA & 9.5 \\
\hline \begin{tabular}{l} 
10. It is not hard to find customers \\
\hline
\end{tabular} & 21 & 23 & 4 & 0 & 3.35 & SA & 5.5 \\
\hline
\end{tabular}

Out of the ten advantages listed, the seventh advantage had the highest mean of 3.63 and a descriptive value of Strongly Agree. It stated that having operational 24-hour convenience stores gave customers enough time to buy commodities without being rushed. The next advantage with the highest mean is item number 5 which stated that the stores will offer more employment or job opportunities. Its weighted mean was 3.60. The third advantage was item number 1 which stated that customers' needs or wants can be bought anytime. The weighted mean was 3.54.

Parallelism on the managers' and customers' views were on Operating 24-hour convenience stores will give customers enough time to buy commodities without being rushed and Customers' needs or wants can be bought anytime. Parallelism is reflected in the study of Xu, Ye, Fan, (2013) where they said that the most effective factor that builds the brand loyalty of 7Eleven customers is its operating hours which is very crucial on attracting or repelling customers.

Least ranked on the list of advantages from the managers' perspective (See Table 2) was It is relatively easy to get started even if it was consi- 
dered an advantage. This finding connects with the theory of constraints, where some managers may have the apprehensions of starting convenience stores because of the high capital needed.

In the eyes of the customers, least rated among the advantages were items The stores are helpful for those who need or want something last minute and You have a certain level of economic stability, even when there are downturns in the local or national economy. These results coincide with the findings of Morash et al., (1997) and Slack et al., (2004) which emphasized the importance of convenience stores as to the comfort of the customers. Hence, the completeness of the product range should be available at any time even at the last minute.

Table 4 presents the disadvantages of having a 24-hour convenience store from the perspective of the managers.

Table 4. Disadvantages of having a 24-hour convenience store (as perceived by the managers)

\begin{tabular}{|c|c|c|c|c|c|c|c|}
\hline \multicolumn{8}{|c|}{$N=5$} \\
\hline Disadvantages & SA & MA & SLA & $\mathrm{D}$ & WM & DV & Rank \\
\hline $\begin{array}{l}\text { It is hard to hire employees who will work in } \\
\text { night-shifts. }\end{array}$ & 0 & 4 & 1 & 0 & 2.8 & MA & 2.5 \\
\hline $\begin{array}{l}\text { 24-hour convenience stores are easy } \\
\text { targets for theft. }\end{array}$ & 0 & 3 & 2 & 0 & 2.6 & MA & 4.5 \\
\hline $\begin{array}{l}\text { It requires more effort to keep a 24-hour } \\
\text { convenience store clean and organized for } \\
24 \text { hours. }\end{array}$ & 0 & 3 & 2 & 0 & 2.6 & MA & 4.5 \\
\hline There will be inventory losses. & 0 & 2 & 3 & 0 & 2.4 & SLA & 7.5 \\
\hline The stocks/commodities are limited. & 0 & 2 & 3 & 0 & 2.4 & SLA & 7.5 \\
\hline Items sold come at higher prices. & 0 & 2 & 2 & 1 & 2.2 & SLA & 9 \\
\hline $\begin{array}{l}\text { It consumes more electricity, water, and } \\
\text { other utilities. }\end{array}$ & 1 & 4 & 0 & 0 & 3.2 & SA & 1 \\
\hline $\begin{array}{l}\text { Working in the night may exhaust } \\
\text { employees and lower their productivity. }\end{array}$ & 0 & 3 & 2 & 0 & 2.6 & MA & 4.5 \\
\hline $\begin{array}{l}\text { It has to spend more on security measures } \\
\text { and devices. }\end{array}$ & 1 & 2 & 2 & 0 & 2.8 & MA & 2.5 \\
\hline $\begin{array}{l}\text { It is more prone to injury, hazards, and } \\
\text { casualties. }\end{array}$ & 0 & 1 & 4 & 0 & 2 & SLA & 10 \\
\hline
\end{tabular}

Out of the ten items, item number 7 , which stated that convenience stores "Consume more electricity, more water, and other utilities" gained the the highest rating. The weighted mean was 3.2. The second-ranked among the listed disadvantages were items 1 and 9 . Item number 1 , stated 
that it is hard to hire employees who will work in night-shifts, while item number 9 stated that It has to spend more on security measures and devices. The weighted mean was 2.80. The third-ranked advantages were items number 2,3 and 8 , with a weighted mean of 2.60. Item number 2 stated that 24-hour convenience stores are easy for theft, item number 3 stated that It requires more effort to keep a 24-hour convenience store clean and organized for 24 hours, and item number 8 stated that Working in the night may exhaust employees and lower their productivity.

Table 5. Disadvantages of having a 24-hour convenience store (as perceived by the customers)

\begin{tabular}{|c|c|c|c|c|c|c|c|}
\hline \multicolumn{8}{|c|}{$N=48$} \\
\hline Disadvantages & SA & MA & SLA & $\mathrm{D}$ & WM & DV & Rank \\
\hline $\begin{array}{l}\text { It is hard to hire employees who will } \\
\text { work in night-shifts. }\end{array}$ & 28 & 10 & 3 & 7 & 3.23 & MA & 9 \\
\hline $\begin{array}{l}\text { 24-hour convenience stores are easy } \\
\text { targets for theft. }\end{array}$ & 20 & 17 & 11 & 0 & 3.19 & MA & 10 \\
\hline $\begin{array}{l}\text { It requires more effort to keep a } 24 \text { - } \\
\text { hour convenience store clean and } \\
\text { organized for } 24 \text { hours. }\end{array}$ & 26 & 21 & 1 & 0 & 3.52 & SA & 1 \\
\hline There will be inventory losses. & 20 & 26 & 1 & 1 & 3.35 & SA & 8 \\
\hline The stocks/commodities are limited. & 24 & 20 & 4 & 0 & 3.42 & SA & 6.5 \\
\hline Items sold come at higher prices. & 25 & 15 & 8 & 0 & 3.5 & SA & 2.5 \\
\hline $\begin{array}{l}\text { It consumes more electricity, water and } \\
\text { other utilities. }\end{array}$ & 22 & 24 & 2 & 0 & 3.42 & SA & 6.5 \\
\hline $\begin{array}{l}\text { Working in the night may exhaust em- } \\
\text { ployees and lower their productivity. }\end{array}$ & 27 & 19 & 1 & 1 & 3.5 & SA & 2.5 \\
\hline $\begin{array}{l}\text { It has to spend more on security mea- } \\
\text { sures and devices. }\end{array}$ & 25 & 21 & 2 & 0 & 3.48 & SA & 4.5 \\
\hline $\begin{array}{l}\text { It is more prone to injury, hazards and } \\
\text { casualties. }\end{array}$ & 25 & 21 & 2 & 0 & 3.48 & SA & 4.5 \\
\hline
\end{tabular}

Table 5 shows the disadvantages of having a 24-hour convenience store from the perspective of the customers. As perceived by the customers, the top-ranked disadvantages in running these stores were, "24-hour convenience stores require more effort to keep it clean and organized for 24-hours," "Working in the night may exhaust employees and lower their productivity and items are sold at higher prices," and "it has to spend more on security measures and devices and that it is more prone to injury, hazards and casualties." 
As revealed in the study of Morash et al., (1997), since only a few people were willing to take graveyard shifts, it required more effort to keep a 24-hour convenience store in order. Also, such findings agree with the Law of Supply and Demand under the theory of Consumer Behavior. The increase in the price of the product leads to the decrease of the customers' inclination to buy. As to the finding of security measures as a disadvantage, such reiterates the lines of Slack (2004), when he said, convenience stores must operate to the convenience of the customers' security. Hence, it would be a deterrent than an asset.

As to the difference between the managers' and customers' responses to the advantages of a 24-hour convenience store, results showed that there was a significant difference between the responses of the managers and that of the customers as to the advantages.

Table 6. Difference between the Managers' and Customers' responses as to the advantages of a 24-hour convenience store.

\begin{tabular}{|l|l|l|l|l|}
\hline ITEM/ADVANTAGE & Manager's Response & Customer's Response & D & D2 \\
\hline SUM & 31.80 & 33.95 & -2.15 & 3.36 \\
\hline MEAN & 3.18 & 3.395 & -0.39 & 0.6103 \\
\hline
\end{tabular}

\begin{tabular}{|c|}
\hline Computed T Value $=2.64$ \\
\hline Critical Value of $\mathrm{T}$ at 9 df at 0.05 level of significance $=2.26$ \\
\hline Result: Significant \\
\hline Decision: Reject Ho \\
\hline
\end{tabular}

As to the relationship between the managers' and customers' responses to the disadvantages of a 24-hour convenience store, results showed that there was a significant difference between the responses of the customers and that of the managers as to the disadvantages of such stores.

Table 7. Relationship between the Managers' and Customers' responses as to the disadvantages of a 24-hour convenience store

\begin{tabular}{|l|l|l|l|l|}
\hline ITEM/ DISADVANTAGE & Manager's Response & Customer's Response & D & D2 \\
\hline SUM & 25.6 & 33.94 & -8.34 & 8.156 \\
\hline MEAN & 2.56 & 3.39 & & \\
\hline \multicolumn{4}{|r|}{ Computed T Value $=7.2213281$} \\
\hline
\end{tabular}


Critical Level of T at 9df and 0.05 level of significance $=2.26$

Result: Significant

Decision: Reject Ho

\section{CONCLUSIONS}

Anchored on the information gathered from interviews and questionnaires, the following conclusions were drawn:

1. Managers and customers were of the same eye on the top advantages of running the stores that were being studied, such as giving the luxury of time to the customers on availing the commodities and its availability at any time;

2. Managers and customers shared the same views on the top disadvantages. Namely, nightshifts are exhausting the employees, thus, lessened the productivity, the cost of the upkeeping, the cleanliness, organization, and security;

3. A significant difference in the views of the managers and customers as to the mentioned advantages and disadvantages of running the convenience stores stood out in the findings.

\section{RECOMMENDATIONS}

1. Implement the Labor law as to the salaries and benefits that should be afforded to employees especially on the differences of salaries on night and day shifts;

2. Care of employees' mental and physical well-being should be done by the business owners;

3. Implement robust security measures to safeguard both the customers, the employees, and properties;

4. Encourage the budding entrepreneurs to cater to the needs of the market of the modern times should be done by the governmental and non-governmental agencies;

5. Use renewable energy, such as solar energy for electricity during nighttime, replace plastics with biodegradable materials, recycle as much as they can;

6. Conduct a regular/periodic quality assurance of the convenience stores by the concerned government agency. 


\section{REFERENCES CITED}

Anderson, E. W., \& Sullivan, M. W. (1993). The antecedents and consequences of customer satisfaction for firms Marketing science, 12(2), 125-143.

Bedell-Pearce J. (2013) "Challenges of Running a Business 24-7". Retrieved from https://goo.gl/qUWYY4, (accessed last 14 January 2017).

Chen, S. C., \& Quester, P. G. (2006). Modeling store loyalty: perceived value in market orientation practice. Journal f Services Marketing, 20(3), 188-198 Retrieved from https://goo.gl/rkK2Yj, (accessed last 5 January 2017).

Coleman, R.M (1995) "The 24-Hour Business: Maximizing Productivity Through Round-the-Clock Operations." Retrieved from https://goo. gl/29DPXV, (accessed last 6 January 2017).

Ferdows, K., \& De Meyer, A. (1990). Lasting improvements in manufacturing performance: in search of a new theory. Journal of Operations Management, 9(2), 168-184. Retrieved from https://goo.gl/F7Kcvy, (accessed last 16 January 2017).

Fukada, T. (2008) "Are 24-hour shops a waste of energy?" Retrieved from https://goo.gl/h1GZzN, (accessed last 7 January 2017).

Gaille, B. (2015)." 8 Pros and Cons of Owning a Convenience Store." Retrieved from https://goo.gl/xPBdQ3, (accessed last 16 January 2017).

Goldratt, E. M. (1990). Theory of constraints. Croton-on-Hudson: North River. Retrieved from https://goo.gl/tZxjus, (accessed last 5 January 2017).

McDonnell, J., Beatson, A., \& Huang, C. H. (2011). Investigating relationships between relationship quality, customer loyalty and cooperation: An empirical study of convenience stores' franchise chain systems. Asia Pacific Journal of Marketing and Logistics, 23(3), 367-385. Retrieved from https://goo.gl/CGBppU, (accessed last 6 January 2017).

Morash, E. A., Dröge, C., \& Vickery, S. (1997). Boundary-spanning inter- 
faces between logistics, production, marketing and new product development. International Journal of Physical Distribution \& Logistics Management, 27(5/6), 350-369.

Philippine Statistics Authority (2016). The population of Region VII-Central Visayas. Retrieved from https://goo.gl/GBBrhE, (accessed last 6 January 2017).

Rainisto, S. K. (2003). Success factors of place marketing: A study of place marketing practices in Northern Europe and the United States. Helsinki University of Technology. Retrieved from https://goo.gl/cBLJhC, (accessed last 5 January 2017).

Slack, N. (1983). Flexibility as a manufacturing objective. International Journal of Operations \& Production Management, 3(3), 4-13.

Slack, N., \& Lewis, M. (2002). Operations strategy. Pearson Education. Retrieved from https://goo.gl/NPnC2C (accessed last 16 January 2017).

Slack, N., Lewis, M., \& Bates, H. (2004). The two worlds of operations management research and practice: can they meet, should they meet?. International Journal of Operations \& Production Management, 24(4), 372-387. Retrieved from https://goo.gl/9TdHYV, (accessed last 16 January 2017).

Stank, T. P., Goldsby, T. J., \& Vickery, S. K. (1999). Effect of service supplier performance on satisfaction and loyalty of store managers in the fast food industry. Journal of operations management, 17(4), 429-447. Retrieved from https://goo.gl/KGKSVq, (accessed last 29 January 2017).

Xu Y., Ye X., \& Fan Z., (2013). The Customer Satisfaction Research of 7-Eleven Stores in Hong Kong. Department of Business Administration, School of Management, Jinan University, Guangzhou, China: SciRes Publishing 